Portland State University

PDXScholar

\title{
A Study Describing the Counseling Practices of the Pastors in the Pacific Northwest Conference of the Free Methodist Church
}

Jere' Slingerland Howell

Portland State University

Follow this and additional works at: https://pdxscholar.library.pdx.edu/open_access_etds

Part of the Social Work Commons

Let us know how access to this document benefits you.

\section{Recommended Citation}

Slingerland Howell, Jere', "A Study Describing the Counseling Practices of the Pastors in the Pacific Northwest Conference of the Free Methodist Church" (1976). Dissertations and Theses. Paper 1805. https://doi.org/10.15760/etd.1799

This Thesis is brought to you for free and open access. It has been accepted for inclusion in Dissertations and Theses by an authorized administrator of PDXScholar. Please contact us if we can make this document more accessible: pdxscholar@pdx.edu. 
A STUDY DESCRIBING THE COUNSELING PRACTICES OF THE

PASTORS IN THE PACIFIC NORTHWEST CONFERENCE OF

THE FREE METHODIST CHURCH

by

JERE' SLINGERLAND HOWELL

A report submitted in partial fulfillment of the requirements for the degree of

MASTER OF

SOCIAL WORK

Portland State University

1976 
TABLE OF CONTENTS

PAGE

LIST OF TABLES .....................

iii

CHAPTER

I INTRODUCTION ..................... 1

II REVIEW OF THE LITERATURE ............ 4

History ................. 5

Types ......................... 8

Function and Principles ......... 10

Goals ............................ 11

III METHODOLOGY ................. 13

Selection of the Sample ................ 13

Selection of the Measuring Instrument .... 14

Collection of Data.................. 14

Data Processing ........................ 15

IV PRESENTATION AND INTERPRETATION OF DATA ..... 16

V SUMMARY AND CONCLUSIONS ............ 33

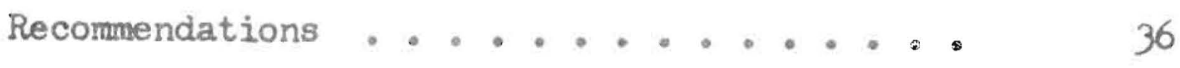

Implications for Further Study ........ 36

BIBLIOGRAPHY ............................. 38

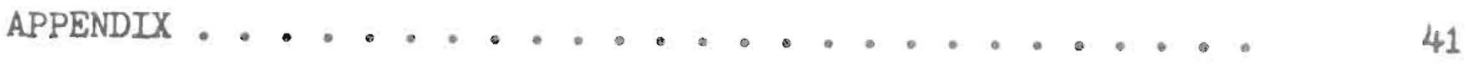


LIST OF TABLES

TABLE

PAGE

I Highest Level of Education Achieved by the Pastors

II Counseling Training by the Number of Counseling Subjects by Name of Course . . . . . . .

III Church Size by the Number of Pastors Who Have Had Counseling Training Since Entering the Pastorate Compared to the Number of Pastors Who Have Not Had Counseling Training Since Entering the Pastorate .............

IV Length of Counseling Session by Pastors Who Have Had Counseling Training Since Entering the Pastorate Compared with Pastors Who Have Not Had Counseling Training Since Entering the Pastorate .............

V The Mean and Range Amount of Ease Felt by the Pastors In Different Counseling Situations .....

VI The Mean and Range Amount of Importance of Certain Goals ............

VII The Mean Amount and Range of Ease Felt by the Pastors in the Different Roles ...........

VIII Counseling Techniques Rated According to the Amount of Utilization by Pastors ......... 
The idea of studying Free Methodist pastors' counseling techniques and knowledge came from two sources. One source was a counseling class taken at the undergraduate level where the counseling methods of Fundamentalist pastors were criticized. This criticism was made without the basis of research. The other source came from taking a counseling class with seminary students at Western Evangelical Seminary.

The study was designed to determine the general knowledge of counseling techniques and procedures by pastors. The research was in no way designed to make value judgments on the effectiveness of pastoral counseling or the appropriateness of techniques utilized by counseling pastors. It has provided a general overview of pastoral counseling within a specific population.

\section{QUESTIONS TO BE STUDIED}

The questions which preoipitated and served as an impetus to the study were as follows:

1. How much training do the pastors have in fulfilling the role of counselor?

2. How important does the pastor feel his counseling is to his total ministry?

3. How much ease does the pastor feel in the role of a counselor?

4. What does the pastor see as his main role while counseling?

5. What types of techniques does the pastor utilize while counseling? 
6. How does the pastor as a counselor handle different situations?

7. What difference exist in counseling between pastors who have had counseling training since entering the pastorate and those who have not had counseling training since entering the pastorate?

\section{DEFINITIONS}

The following definitions were used in this research.

Free Methodist is a Protestant denomination founded in 1860 by B. T. Roberts. The denomination builds much of its doctrine on the works of John Wesley and the major emphasis is on "holiness."

Fundamentalism is a belief in the Bible as a factual historical record and the belief in controvertible prophecy, including such doctrine as the Genesis, the Virgin Birth, the Second Advent, and Armageddon。 (Morris, 1970, p.533.)

Pastoral Counseling, according to Carrol Wise (1951, p.4.), is a process through which people have been helped to grow, meet and solve problems, and achieve mature religious lives.

Senior Pastor is the head pastor of the church, appointed to that position by the conference superintendent. In his capacity as pastor, he has spiritual charge over the congregation and is authorized to perform religious functions.

Techniques as defined by Morris (1970, p. 1321.) are the systematic procedures by which the task is accomplished. 


\section{CHAPTER II}

REVIEW OF THE LITERATURE

The review of the literature will provide a general overview of the field of pastoral counseling. For ease in reading the review has been divided into five parts. They were as follow:

1. Introduction

2. History

3. Types

4. Functions and Principles

5. Goals

\section{INTRODUCTION}

Members of the congregation often turn to their pastor for guidance and counseling. In a study published by the University of Michigan in 1960, it was found that one out of every seven had sought professional help for an emotional problem. Forty-two percent of these people went to their clergyman first. (Gurin, 1960, p. 307.)

It was also supposed that in areas where no mental health practitioner worked or lived, that the people with emotional problems or conflicts seek out their pastor for help.

When these two points were combined, it was indicated that a large segment of the population seek out their pastor when they are in need of help. 


\section{HISTORY}

People since their beginnings as human beings have consulted with the witch doctors and the priest healers for guidance on the miracles and mysteries of life. This need for pastoral counseling arose out of man's primitive needs for survival. (Stein, 1960, p. 11.)

In Old Testament times, the disputes and problems were dealt with by the head of the family. When leading the Jews out of Egypt, Moses handled most of the disputes. The job of counseling all the people became too much for him, therefore, he selected men who handled the problems within their own families and gave them the responsibility of counseling small groups. (Oates, 1959, p. 4.)

Samuel was another outstanding counselor out of the old Testament. He rode a circuit, hearing controversies, giving judgments, teaching and counseling. (Oates, 1959, p.4.)

Jesus of Nazareth was acclaimed as a counselor's ideal. He was a compassionate man, who had a unique insight into people and their behavior. Jesus demonstrated the qualities of sympathy, honesty, sincerity and patience. (Oates, 1959, p. 5.)

In the Letters of the Apostle Paul to the early churches, basic ideas on pastoral counseling were presented. Paul responded in his letters to problems that the people had concerning inter-faith marriages. divorce, sexual promiscuity, husband-wife relationships, and parentchild relationships。 (First Corinthians, seven, and Ephesians, four and five.)

Two writers who came out of the Age of the Church Fathers were John Chrysostom and Ambrose. Chrysostom wrote the book, Treatise 
on the Priesthood which spelled out pastoral duties. As a spiritual counselor, he spoke out for a more humane treatment of sinners. He showed the awareness that a person can not be helped if he does not want to be helped. (Oates, 1959, p.6.)

Ambrose of Milan wrote Three Books on the Duties of the Clergy. In these writings he said that the character of the counselor determined whether or not the people would seek help. (Oates, 1959. p. ?.)

The "Penitentials" was a manual for Catholic priests to use in the assigning of penance. The main purpose of the manual was the reconstruction of the personality. (Oates, 1959, p. 8.)

It was not until the Protestant Reformation that the duties of the pastor were emphasized. Martin Luther wrote Letters of Spiritual Counsel. In this book, Luther handled issues relating to marriage and sex. (Oates, 1959, p. 9.) Martin Baucer, another reformation pastor, wrote a book, On the True Care of Souls. He stressed that the people need individual Christian guidance. (Oates, 1959, p. 9.)

Because of the new situations that were created by the changing Puritan society, the people felt an acute need for guidance. The atmosphere of moral ernestness prevailed throughout this period of pastoral counseling. "Cases of Conscience," a manual composed during this time, was concerned with family life, military service, economic activities, and the uses of recreational activities. (Oates, 1959, p. 10)

The Reformed Pastor written by Richard Baxter encouraged pastors 
in a method of private instruction of families. Baxter suggested three things which depressed people should avoid. They were: blaming their depression on the Spirit of God, having contact with objects that tempt, and placing religion in a category with "too much fears, tears, and scruples." (Oates, 1959, p.11.)

The nineteenth century produced two prominent pastoral counselors. Horace Bushnell wrote a book entitled Christian Nurture. In this book, he presented the idea that infancy played an important role in the development of an individual. He encouraged parents to be gentle, patient, and loving in caring for their children. (Oates, 1959, p. 13.)

Washington Gladden, in his book The Christian Pastor, encouraged the pastor to be a friend that others in the community could turn to. He also encouraged the co-operation between pastors and the medical profession. (Oates, 1959, p. 13.)

Near the end of the nineteenth century, the psychology of religion began to be studied. In 1899, in the School of Religious Fedagogy of Hartford Theological Seminary, the first course of its kind was taught, called The Psychology of Religion.

During the same time period, Henry Drummond began advocating clinical counseling training for seminary students. It was not until 1923. that any clinical training was offered. Dr. William Keller, a physician, began training seminarians in counseling skills during the summer months. In 1925, under the leadership of Anton T. Boisen a chaplaincy program was started at Worchester State Hospital in Massachusetts. This program required that the pastors accept the same 
disciplines required of those in other counseling professions.

In 1939, Rollo May wrote the book The Art of Counseling.

This book was composed of lectures given on the personality resulting

from the works of Adler, Freud, Jung, Rank, and Kunkle. May was

a student of Boisen.

From the early beginnings emphasis has grown in the field of clinical pastoral training.

"There is little question but that clinical pastoral training has been the most valuable single influence in enabling the present day pastor to function effectively as a counselor." (Oates, 1959, p. 1.7.)

\section{TYPES}

Four basic types of pastoral counseling have been defined:

1. The Client-Centered Approach - Carl Rogers

2. Crisis Theory - Howard Stone

3. The Revised Model - Howard Clinebell

4. Nouthethic Counseling - Jay Adams

During the forties and fifties, the client-centered approach had a big effect on the training and practice of pastoral counseling. It called for the pastor to be reflective and passive. (Clinebell, 1966, p. 28.) In client-centered therapy the phases present are:

1) the establishment of rapport and the structure of the therapeutic relationship, 2) the expressive stage, 3) the emergence of insight which produces changes in self-perception and behavior, 4) the closing phase in which the relationship is terminated. (Clinebell, 1966, p. 274.) Carroll A. Wise in his book Pastoral Counseling; It's Theory and Practice 
and Seward Hiltner in his book Pastoral Counseling applied the client-centered approach to pastoral counseling.

Howard Stone (1972, p. 65.) said in his book Suicide and Grief.

"The methods I am presenting are valuable but only as building blocks on top of the minister's fundamental ability to develop rapport with his parishioner. To give also, an idea of ways in which he can foster and encourage this relationship."

The "ABC" method of crisis intervention developed by Dr. Warren Jones, Stone felt was the best suited technique for counseling pastors. It follows three basic steps:

1. To achieve contact, which means establishing a therapeutic relationship. This is accomplished by listening and asking questions that focus on feelings and behavior and by letting one know that one cares about him.

2. Boiling down, which involves focusing in on the feelings and the components of the problem. This helps bring the person out of his "tailspin."

3. Challenging the person to cope, which involves helping one actually do something about his situation. (Stone, 1972, p. 72-75)

Howard J. Clinebell Jr. (1966, p. 27-28.) devised the Revised Model for pastoral counseling. Following are the principles of the model:

1. Using supportive methods

2. Helping the person to improve relationships

3. Helping the person to maximize and utilize one's positive personality resources

4. Helping the person cope successfully with one's current 
situation and in planning for the future

5. Making direct efforts to increase the constructiveness

and the creativity of behavior of the person

6. Dealing directly with the crucially important vertical dimensions.

Jay Adams (1970, p. 44-50.) developed the idea of Nouthetic counseling. The characteristics of the Nouthetic counseler were goodness and knowledge and the ability to confront and admonish one. It also required that the counselor be conversant with the Scriptures and have wisdom. This type of counseling was based around Nouthetic confrontation. The first element of Nouthetic confrontation was the implication that someone has a problem and that there is some way to overcome it. The second element was that the problem may be solved verbally. The third element was that the intention of the verbal correction is to benefit the counselee. The purpose of this type of counseling was to y effect personality and behavior change. $+4$

\section{FUNCTIONS AND PRINCIPLES}

William A. Cubain and Charles R. Jackle identified four pastoral care functions. (Clinebell, 1966, p.39.) They were: a)healing a pastoral function that aims to overcome some impairment by restoring the person to wholeness and by leading him to advance beyond his pervious condition, b)sustaining - helping a hurting person to endure and transcend a circumstance in which restoration to his former condition or recuperation from his malady is either impossible or so remote as to seem improbable, c)guiding - assisting perplexed persons 
to make confident choices between alternative courses of thought and action, when such choices are viewed as affecting the present and the future state of the soul, d) reconciling - seeks to re-establish the broken relationships between man and fellow man and between man and God.

Calvert Stein (1970, p. 10.) Iisted six principles for the counseling relationship. They are:

1. Meditation or thinking things over.

2. Allowing the client to sound off - ventilation or the expression of thoughts and grief.

3. Allowing the emotional release from tension and anxiety.

4. Helping the cleansing process through confession and ritual.

5. Sacrifice, payment or penance as atonement.

6. The reformation of the client's behavior.

The counseling session, as set up by Stein, provides a climate in which the client is able to ventilate his feelings. find a release from tension and anxiety, and change his behavior.

\section{GOALS}

The literature on pastoral counseling contained information on the setting of goals. Charles F. Kemp (1971, p. 25.) Iisted eleven goals that the pastor should have in working with the client. These goals follow:

1. Reduce undue tension

2. Resolve harmful conflicts

3. Improve insight and self-understanding 
4. Increase self-acceptance

5. Release intemal resources

6. Provide information

7. Foster continued growth

8. Make realistic choices

9. Improve interpersonal relationships

10. Attain self-fulfillment and self-actualization

11. Deepen spiritual resources

Hiltner (Clinebell, 1966, p. 31.) felt that the goal of counseling was new insight with proof and action. Clinebell (1966, p. 20.) asserted the master goal of counseling to be,

"Pastoral counseling is the utilization, by a minister, of a one-to-one or small group relationship to help people handle their problems of living more adequately and grow toward fulfilling their potentialities. This is achieved by helping them reduce the inner blocks which prevent them from relating in need-satisfying ways."

Clinebell (1966, p. 32.) went on to say that insight is an appropriate goal for those persons who have considerable ego strength; inner resources; the capacity for introspection and the motivation to do more than solve their immediate problems. However, he felt that insight should become a secondary and optional goal to the goal of enhancing a person's ability to relate in mutually need satisfying ways.

An overview of the pastoral counseling literature has been presented in this chapter. The review provided some insight into the background of the pastoral counseling field. A variety of goals and counseling techniques were found to exist in the literature. 
CHAPTER III

METHODOLOGY

\section{SELECTION OF THE SAMPLE}

When the plans for this study were first initiated, it was decided to use as the population the senior ministers of the Pacific Northwest Conference of the Free Methodist Church. This population was selected because of its proximity and the author's knowledge of it. A considerable variety of ministers and churches exist within the conference. Information from the Conference office revealed that there were fifty-six churches in the conference, nine of these churches were located in Canada. It was decided to eliminate the Canadian churches from the sample because they were outside the United States. This brought the population down to forty-seven. Because of the small population, it was decided to poll the entire population. It was thought that if the whole population was contacted the results would be more valid and reliable than if a sample was selected.

Although the entire population was contacted, forty-two responded. The actual sample was composed of large churches, small churches, city churches, small town churches, rural churches, churches with pastors who had much experience in the ministry and churches with pastors who had little experience in the ministry. The actual sample provided a look at a variety of aspects of the Pacific Northwest Conference of the Free Methodist Church. 


\section{SELECTION OE THE MEASURING INSTRUMENT}

It was decided that a questionnaire would be prepared to collect the data. Questionnaires were mailed to the pastors with instructions to complete it and return it. An attempt was made to create the questionnaire in such a manner that it would be easy to answer, easy to understand, and interesting enough that the pastors would take the time to answer.

A preliminary questionnaire was given to twenty Western Evangelical Seminary counseling students as a pretest.

The aim of the questionnaire was to obtain data regarding who does how much counseling, through what media, with what value references, what roles, aims, and facility, associated with what background training. Hence, qualitative, ordinal, and interval data were sought. (in Appendix)

\section{COLLECTION OF DATA}

The final questionnare, along with a letter of introduction, and a letter from the Conference superintendent, was mailed with a self-addressed, stamped envelope to each of the forty-seven pastors on January 7, 1976. Each questionnaire was numbered in the upper right hand corner for follow up contact if the need arose. After receiving the returned questionnaire, the number was removed, insuring the anonymity of the respondent. By the first of February, thirtyfive questionnaires were returned. It was decided that a follow up letter and a second copy of the questionnaire should be sent out to seven of the twelve who did not respond to the first. The names 
were placed in a bowl and seven names were drawn. The follow up letter and questionnaire were mailed on February 7, 1976. Three questionnaires crossed in the mail, two who received the follow up letter answered, and one who did not receive the follow up letter answered. By February 14, 1976, forty-two questionnaires were returned. This was an eighty-nine percent return of the questionnaires. The non-respondents did not differ from those who did respond in terms of location and size of church. The educational background and counseling training are not known for the pastors who did not respond.

\section{DATA PROCESSING}

The data on the returned questionnaires was transferred onto a large tally sheet. From this tally sheet frequency distributions for each question was computed. The mean for appropriate questions was computed, as was the standard deviation and the standard error of the mean, and the range. Correlations between various questions were computed. Chi Square, as well as the difference between means were computed to compare those who had counseling training with those who did not have, prior to entering the pastorate and after. 
In this section the results of the questionnaire are presented.

Years in the Pastorate Full Time

There were forty-two responses to this question. The number of years in the pastorate ranged from .5 years to forty-two years. The mean number of years was 16.69 and the standard deviation was 13.22 .

Highest Level of Formal Education

Forty-two responded to this question. Because of the method used in the Free Methodist Church to become a pastor it was expected that there would be a large range in terms of the formal education achieved. The responses to this question fulfilled the expectations.

\section{TABLE I}

HIGHEST LEVEL OF EDUCATION

ACHIEVED BY THE

PASTORS

Level of education Frequency Percent of total

High School

Less than B.A.

B.A. Less than Master's

Master's

Less than Doctorate

Doctorate

$\begin{array}{rr}2 & 4.76 \\ 7 & 16.67 \\ 6 & 14.29 \\ 6 & 14.29 \\ 13 & 30.95 \\ 7 & 16.67 \\ 1 & 2.38\end{array}$

\section{Seminary Attended}

Twenty-four pastors out of the forty-two responding attended seminary. Eleven attended Asbury Theological Seminary in Wilmore, Kentucky. Eight attended Western Evangelical Seminary in Milwaukie, 
Oregon. Two pastors attended both Asbury Theological Seminary and Western Evangelical Seminary. Two pastors attended Eden Seminary in St. Louis, Missouri. One pastor attended Winona Lake Seminary in Winona Lake, Indiana.

\section{Counseling Training}

One aspect this study was to assess was the amount of counseling training the pastors have had. The pastors received their counseling training from college classes, seminary classes, and other sources since entering the pastorate.

Nine pastors had counseling classes in college. Counseling classes were taken in seminary by fourteen pastors. Seventeen pastors received counseling training from sources other than college or seminary classes. Pastors who have had some kind of counseling training since entering the pastorate numbered twenty - eight.

Included in the list of counseling training was the seminar, Basic Youth Conflicts. This seminar, conducted by Bill Gothard, deals with Biblical principles applied to the family. Since entering the pastorate twenty-eight pastors have taken Basic Youth Conflicts.

It was expected that there would be a difference in how the pastors counseled depending on their training. The pastors were separated into two groups; those who had had counseling training since entering the pastorate and those who had not had counseling training since entering the pastorate. There were twenty pastors who had had counseling training excluding Basic Youth Conflicts since entering the pastorate. Twenty-two pastors had had no training since entering the pastorate. 


\section{TABLE II}

COUNSELING TRAINING BY THE NUMBER

OF COUNSELING SUBJECTS BY

NAME OF COURSES

\begin{tabular}{lccccc} 
Subjects & College & Seminary & Other & Post seminary & Total \\
\hline Theory & $?$ & 9 & 7 & & 23 \\
Family & 6 & 6 & 10 & & 22 \\
Marital & 5 & 6 & 9 & & 20 \\
Individual & 7 & 7 & 8 & & 22 \\
Adolescent & 4 & 2 & 3 & & 9 \\
Other & 2 & 1 & 1 & & 4 \\
Total & 31 & 31 & 38 & & \\
Marital & & & & 13 & 15 \\
Pre-marital & & & & 10 & 13 \\
Family & & & & 1 & 2 \\
TA & & & & 28 & 1 \\
Gestalt & & & & 3 & 28 \\
Reality & & & 38 & 77 & 3 \\
Basic Youth & & & & & \\
Other & & & & & \\
Total & & & & &
\end{tabular}


Size of the Congregation

The size of the congregations ranged from under fifty to over four hundred. Those pastors who have had counseling training since entering the pastorate tend to have larger churches than those who have not had counseling training since entering the pastorate.

TABLE III

CHURCH SIZE BY THE NUMBER OF PASTORS WHO HAVE HAD COUNSELING TRAINING SINCE ENTERING THE PASTORATE COMPARED TO THE NUMBER OF PASTORS WHO HAVE NOT HAD COUNSELING TRAINING SINCE ENTERING THE PASTORATE

\begin{tabular}{lccc} 
Church size & $\begin{array}{l}\text { No. of } \\
\text { Pastors had }\end{array}$ & $\begin{array}{c}\text { No. of } \\
\text { Pastor had not }\end{array}$ & Total \\
\hline under 50 & 3 & 8 & 11 \\
$50-99$ & 3 & 5 & 8 \\
$100-149$ & 3 & 6 & 9 \\
$150-199$ & 7 & 1 & 8 \\
$200-249$ & 0 & 1 & 1 \\
$250-299$ & 2 & 1 & 3 \\
$300-349$ & 1 & 0 & 1 \\
$350-399$ & 0 & 0 & 0 \\
400 and over & 1 & 0 & 1 \\
Total & 20 & 22 & 42
\end{tabular}

Hours Per Week Spent in Counseling Sessions

The amount of time spent per week in counseling sessions ranged in hours from under three hours to between eleven and fifteen hours. Pastors who counseled under three hours a week numbered twelve. Twentythree pastors counseled between three and five hours a week. Between six and ten hours a week was the average amount of time spent in counseling for five pastors. One pastor spent between eleven and fifteen hours a week in counseling sessions.

In a study conducted by Eaton (1963, p. 93-105) of thirty-four suburban Pittsburg pastors, it was found that thirty percent of the pastor's time was spent in counseling sessions. The pastors in 
the Pacific Northwest Conference of the Free Methodist Church, in general, spent twelve and one-half percent or less of a forty hour week in counseling sessions. The hours per week that a pastor spent counseling may have been affected by the size and the location of the church and the size of the ministerial staff.

A correlation ratio (eta) was computed to see whether the size of church was a function of the amount of time spent in counseling by the pastor. An $\mathrm{F}$ test indicated the ration (.62?) was not significant even at the ten percent level of confidence. Any effect of counseling hours on church size was too small to be considered. Both church size and hours counseled clustered in the lower numerical values.

\section{Place of Counseling}

The question was asked to determine the setting where most of the counseling sessions were conducted. The pastors were to rate from one to five, with one being the most, where most of the counseling sessions occurred. It was expected that most of the counseling sessions would be conducted in the pastor's office. Out of the forty who responded to the question, twenty-three did most of their counseling in their office, thirteen pastors counseled the most in the person's home, seven conducted most of their counseling sessions over the telephone, and four pastors check two answers.

\section{Length of Counseling Session}

Many counseling agencies, generally, counsel for an hour per session. It was expected that the pastors would spend a similar amount of time in counseling sessions. The mode amount of time spent in 
counseling sessions was between thirty and forty-nine minutes. As an average, three pastors spent under thirty minutes in their counseling sessions. Eighteen pastors, on the average, had counseling sessions thirty to forty-nine minutes in length. Pastors who spent between fifty and eighty-nine minutes in their counseling sessions numbered seventeen. Two pastors spent ninety minutes and over in their counseling sessions.

\section{TABLE IV}

LENGTH OF COUNSELING SESSION BY PASTORS WHO HAVE HAD COUNSELING TRAINING SINCE ENTERING THE PASTORATE COMPARED WITH PASTORS WHO HAVE NOT HAD COUNSELING TRAINING SINCE ENTERING THE PASTORATE

\begin{tabular}{lccc} 
Length & $\begin{array}{l}\text { No. of } \\
\text { Pastors had }\end{array}$ & $\begin{array}{l}\text { No. of } \\
\text { Pastors had not }\end{array}$ & Total \\
\hline under 30 min. & 0 & 3 & 3 \\
$30-49$ min. & 9 & 9 & 18 \\
$50-89$ min. & 10 & 7 & 17 \\
90 min. and over & 1 & 1 & 2 \\
Total & 20 & 20 & 40
\end{tabular}

Importance of Counseling to Total Ministry.

The question was designed to determine the amount of importance the pastors felt that counseling was to their total ministry. It was expected that most of the pastors would rate counseling as an important aspect of their ministry. Generally, those expectations were fulfilled. One pastor felt that counseling was not important to his total ministry. Two pastors felt the counseling aspect of their ministry to be somewhat important to their ministry. Twelve pastors considered counseling to be a moderately important aspect of their ministry. Counseling was regarded as an important aspect of their ministry by fifteen pastors. Twelve pastors belleved the counseling part of their ministry was very important. 
When the pastors were separated into two extremes, those who had no counseling training at all and those who had three or more counseling courses since entering the pastorate, percentage wise more of those pastors who had three or more courses felt counseling to be important to their ministry.

Ease in Counseling

This question was designed to find the amount of ease the pastors felt in different counseling situations. The mean degree of ease for each situation was computed on a scale of zero to one hundred.

It was expected that the pastors would feel the greatest level of ease in counseling people with spiritual problems. This expectation was met in terms of the mean degree of ease. It was also expected that the pastors would feel little ease in counseling people with a different value system and people who were alcholics. These two expectations were met relatively in terms of the mean degree of ease, though the ease experienced was above the middle scale somewhat. When the pastors were separated into two groups, those who had had counseling training since entering the pastorate and those who had not had counseling training since entering the pastorate, it was found that there was no significant differences between the two groups on the level of ease in any situation.

The two extremes, those who had had three or more counseling courses since entering the pastorate and those who had no training at all, were compared in terms of mean ease. There was no significant difference in means between the two groups at the .1 confidence level 
for one-tailed tests for marital, pre-marital, adolescent, individual, and alcoholic counseling. A significant difference in the means was found for counseling non-church members, counseling church members, counseling a person with a different value system, counseling a person with a spiritual problem and counseling a family. The pastors who had no counseling training had a significant higher mean level of ease. This is a statistically valid comparison for descriptive purposes only and no inferences are drawn.

\section{TABLE V}

THE, MEAN AND RANGE AMOUNT OF EASE FELT BY THE PASTORS IN DIFFERENT COUNSELING SITUATIONS

\begin{tabular}{llll} 
Situation & Mean & Range & No. of Responses \\
\hline Spiritual problem & 87.38 & $50-100$ & 40 \\
Individual & 83.75 & $50-100$ & 40 \\
Church member & 82.63 & $50-100$ & 40 \\
Pre-marital & 81.05 & $25-100$ & 38 \\
Non-church member & 76.75 & $25-100$ & 40 \\
Adolescent & 73.02 & $25-100$ & 38 \\
Family & 72.84 & $25-100$ & 37 \\
Marital & 71.18 & $10-100$ & 38 \\
Diff. value system & 65.39 & $10-100$ & 38 \\
Alcoholic & 52.37 & $0-100$ & 38
\end{tabular}

Goals

This question was designed to assess the importance to the pastors of certain goals. It was expected that the most important goal while counseling would be to bring the person to a greater relationship with God. This expectation was met. The mean degree of importance for this goal was 96.98 .

It was thought that the other goals would be similar to one another in importance. This expectation was not met. There was found to be a difference in means between the different goals. (See questionnaire) 
The range of importance ascribed to the goal to help the person become more functional and to the goal to help the person achieve the goals that he has set for himself was wide. While the goal to help the person to feel better about himself and the goal to bring the person to a greater relationship with God were more generally in the upper range of importance. The goal to bring the person to a greater relationship with God and the goal to help the person achieve the goals that he has set for himself were at the extremes and so were significantly different in importance compared to the middle value.

\section{TABLE VI}

\section{THE MEAN AND RANGE AMOUNT OF IMPORTANCE \\ OF CERTAIN GOALS}

\begin{tabular}{|c|c|c|c|}
\hline Goal & Mean & Range & No, of responses \\
\hline $\begin{array}{l}\text { Bring the person } \\
\text { to a greater } \\
\text { relationship } \\
\text { with God }\end{array}$ & 96.1 & $60-100$ & 41 \\
\hline $\begin{array}{l}\text { Help the person } \\
\text { resolve conflict }\end{array}$ & 84.25 & $30-100$ & 40 \\
\hline $\begin{array}{l}\text { Help the person } \\
\text { become more } \\
\text { functional }\end{array}$ & 80 & $20-100$ & 38 \\
\hline $\begin{array}{l}\text { Help the person } \\
\text { feel better } \\
\text { about himself }\end{array}$ & 79.76 & $50-100$ & 41 \\
\hline $\begin{array}{l}\text { Help the person } \\
\text { achieve his own } \\
\text { goals }\end{array}$ & 96.1 & $60-100$ & 41 \\
\hline
\end{tabular}


Main Role

It was expected that the pastors would feel that the role of spiritual guide was their main role while counseling. This expectation was not met. Forty-one pastors responded to the question. However, thirteen answered with more than one answer. Therefore, the base for this question was twenty-eight. Twelve pastors considered their main role to be that of a listener. The role of spiritual guide was considered the main role of nine pastors. The role of helper was thought to be the main role by three pastors. The role of advisor, comforter, motivator, and therapist was thought to be the main role of one pastor each.

The roles of helper, listener and spiritual guide when grouped together composed eighty-five percent of the total responses.

\section{Amount of Ease in Role}

This question was designed to assess the ease that the pastor had in his various roles while counseling. It was expected that the greatest degree of ease would be in the role of spiritual guide. This expectation was met. The mean degree of ease was 88.02. This was the highest mean level among the different roles.

It was expected that the pastors would feel the least ease in the role of therapist. This expectation was met. The mean level of ease felt in the role of therapist was 50.39 , the lowest of any role. When the pastors were separated into two groups, those who had counseling training since entering the pastorate and those who had not, it was found that there was no significant differences between means except for the level of ease in the role of therapist. The pastors 
who had had counseling training since entering the pastorate had a higher level of ease in the role of therapist than the pastors who had not had counseling training since entering the pastorate.

TABLE VII

THE MEAN AMOUNT AND RANGE OF EASE FELT BY THE PASTORS IN THE DIFFERENT ROLES

\begin{tabular}{llll} 
Role & Mean & Range & No. of Responses \\
\hline Spiritual & 88.02 & $50-100$ & 41 \\
guide & & & \\
Listener & 86.75 & $50-100$ & 40 \\
Helper & 78.59 & $30-100$ & 39 \\
Comforter & 74.25 & $30-100$ & 40 \\
Advisor & 67.37 & $30-100$ & 38 \\
Motivator & 66.28 & $0-100$ & 39 \\
Therapist & 50.39 & $0-100$ & 38
\end{tabular}

Counseling Techniques

A question was designed to explore the different types of techniques utilized by the pastors while counseling. A standardized list of interventive techniques were given to the pastors to rate according to how often the techniques were used. (Appendix, question number nineteen.) 
TABLE, VIII

COUNSEIING TECHNIQUES RATED ACCORDING TO THE AMOUNT OF UTILIZATION BY PASTORS

\begin{tabular}{|c|c|c|c|c|c|c|}
\hline Choices & Very often & $\begin{array}{l}\text { Numb } \\
\text { Orten } \\
\end{array}$ & $\begin{array}{l}\text { er of Resp } \\
\text { Sometimes }\end{array}$ & $\begin{array}{l}\text { nses } \\
\text { Seldom }\end{array}$ & Very seldom & Total \\
\hline Confrontation & 2 & 8 & 10 & 7 & 11 & 38 \\
\hline Clarification & $?$ & 18 & 10 & 2 & 0 & $3 ?$ \\
\hline Ventilation & 5 & 7 & 13 & 6 & 5 & 36 \\
\hline Limit Setting & 1 & 1 & 5 & 9 & 15 & 31 \\
\hline Interpretation & 5 & 11 & 14 & 4 & 2 & 36 \\
\hline Support & $?$ & 12 & 13 & 4 & 4 & 40 \\
\hline $\begin{array}{l}\text { Demonstrate } \\
\text { behavior }\end{array}$ & 0 & 3 & 11 & 4 & 15 & 33 \\
\hline Give Information & 4 & 10 & 13 & 6 & 3 & 36 \\
\hline Persuasion & 2 & 4 & 16 & 8 & 5 & 35 \\
\hline Advice & 2 & 11 & 14 & 9 & 2 & 38 \\
\hline \multicolumn{7}{|l|}{ Conscious } \\
\hline permissiveness & 0 & 2 & 5 & 6 & 16 & 29 \\
\hline $\begin{array}{l}\text { Logical } \\
\text { discussion }\end{array}$ & 4 & 14 & 9 & 2 & 4 & 33 \\
\hline Investigation & 3 & 10 & 9 & 5 & 6 & 33 \\
\hline $\begin{array}{l}\text { Solicit reaction } \\
\text { (support) }\end{array}$ & 0 & 3 & 13 & 6 & 6 & 28 \\
\hline $\begin{array}{l}\text { Solicit reaction } \\
\text { (counteract) }\end{array}$ & 0 & 1 & 8 & 7 & 10 & 26 \\
\hline Purposive program & 3 & 9 & 6 & 4 & 8 & 30 \\
\hline
\end{tabular}

Two techniques that were not included were prayer and scripture reading. Tweedie (Couch, 1963, p. 180.), Hilter (1949, p. 164.), and Wise (1951, p. 164.) stressed the importance and legitimacy of prayer and scripture reading during counseling sessions.

The techniques of clarification, support, and logical discussion were the techniques that were used in general more often than the other techniques. The techniques of limit setting, demonstrating behavior, and conscious permissiveness were in general the least used techniques by the pastors.

In using the various techniques there was very little difference in general between pastors who had had counseling training since entering 
the pastorate and those pastors who had not had counseling training since entering the pastorate. Two variables that may have had an affect were: eleven of the twenty-two pastors who had not had counseling training since entering the pastorate had had counseling training prior to entering the pastorate, the years of experience in the pastorate may have affected the usage of different techniques.

Counseling an Adolescent

A series of questions was designed to assess the manner in which the pastor counseled an adolescent. A situation was created where a mother brought her teen-age son in for counseling after he was suspended from school for smoking marijuana. The pastor checked the answer that was the closest to how he would handle the situation.

No pastor responded that he would tell John that it was wrong to smoke marijuana. No pastor responded that he would reassure and support the parents. Four pastors responded that they would explore with John some of the things that were happening at school and at home. Nineteen pastors responded that they would ask the mother to leave and attempt to build a relationship with John. Five pastors answered that they would explore with John and his mother some of the things that were happening within the family. These answers were the responses to how the pastors would handle the situation.

When asked what the pastors would do first in counseling John and his mother, twenty-one pastors responded that they would find out the facts behind the incident, seven pastors answered that they would find out what expectations they had, one checked that he would reassure and 
comfort John, two pastors responded that they would reassure and support the mother.

The next step in counseling John and his mother was determined. Twenty pastors replied that they would find out what things were going on at home and twelve pastors responded that they would set and clarify goals for the session. No pastor responded that they would find out how John was doing in school or that they would discuss ways of punishing John,

In general, the pastors believed that the building of a relationship to be important. They also considered the facts behind the incident to have some importance.

\section{Importance}

Two questions were constructed to determine what aspects the pastors deemed important while counseling a family and while counseling an adolescent. A list describing the aspects of the family and of the adolescent were given to the pastors.

In general, pastors considered the same things as social workers to be important when counseling a family and when counseling an adolescent. In addition, most pastors considered whether the family members or the adolescent were Christian to be an important aspect.

\section{General Statements Concerning Counseling}

A group of questions were designed to assess the pastor's perceptions of different propositions concerning counseling. The pastors were asked to estimate the amount of truth they believed each statement to have be marking little or not truth, some truth or 
much or all truth.

Concerning the statement "A counselor should try not to make value judgements about the client's behavior," nineteen pastors believed there was some truth, fifteen pastors felt there to be much truth.

The proposition "A counselor should not communicate to the client his ideas about the rightness or wrongness of the client's behavior," was believed to contain some truth by twenty pastors, much truth by three pastors and little truth by fifteen pastors.

Regarding the principle "A goal of counseling is human betterment," four pastors responded there was little truth, eight felt there was some truth and thirty felt there was much truth.

Thirty-five pastors believed there to be much truth in "A counselor should look at his client in terms of the client's total life situation." Six pastors felt some truth existed in the statement and one felt there was little truth to it.

Regarding the assertation, "An important characteristic of a counselor is compassion," twenty-eight believed there to be mach truth, while thirteen felt there was some truth.

To the statement, "A counselor should try to relieve a client's guilt and anxiety," sixteen responded with much truth, fourteen felt some truth, and ten felt little truth. An important counseling principle, "All client's are individuals and should be treated as such," was viewed as having much truth by thirtyeight pastors, some truth by three pastors and no truth by one pastor. The assertation "A counselor should give advice to his client," 
was believed to have much truth by eight pastors, some truth by twentyfive pastors and little truth by eight pastors.

The proposition "Change in a person begins when the person makes the decision that he is going to change," was viewed as having much truth by twenty-eight pastors, some truth by twelve pastors and little truth by two pastors.

Twenty-seven pastors responded that there was much truth to "The relationship between the client and the counselor is one of the most important aspects of the counseling situation." Eleven felt there was some truth and four felt there to be little truth to the statement. It was expected that most of the pastors would believe there to be much truth in "As a counselor, the pastor must remember that he represents God's law to his clients." Twenty-seven pastors felt there was much truth, eleven believed it contained some truth and four responded with little truth.

"A counselor should avoid putting his value system on the client," was believed to contain some truth by twenty pastors and elven pastors responded both that there was mouh truth and little truth to the statement.

The principle "The responsibility for change is on the client," was believed to have much truth by twenty pastors, some truth by eleven pastors and little truth by one pastor.

Regarding the assertation. "It is often better to do things for the client than to get the client to do things for himself," forty pastors responded with little truth, one pastor believed there was some truth and one pastor felt it had much truth.

Twenty-four pastors felt that there was some truth to "A counselor 
should treat the spiritual problem and the mental problem will go away." Sixteen pastors believed it contained little truth and two believed it had much truth.

"A counselor should treat the problem as an emotional-mental problem and the spiritual problem will no away," was viewed as having little truth by thirty-five pastors, some truth by six pastors and much truth by one pastor.

The assertation, "A counselor should treat the problem as being both a spiritual and an emotional problem for the best results," was seen as having much truth by twenty-nine pastors, some truth by eleven pastors and little truth by two pastors.

The statement, "A person's mental health has very little to do with the spiritual problem," was believed to have little truth by thirtysix pastors, some truth by two pastors and much truth by four pastors. Most of the pastors responded to all of the questions. Their responses provided an insight into the counseling techniques, training and methods of pastors in the the Pacific Northwest Conference of the Free Methodist Church. 
CHAPTER V

SUMMARY AND CONCLUSIONS

This study was designed to assess the counseling practices of the pastors in the Pacific Northwest Conference of the Free Methodist Church. A questionnaire was sent to the forty-seven senior pastors in the conference excluding those pastors residing in Canada. Forty-two questionnaires were returned and it was from these forty-two that inferences were made. Seven questions were established and considered during this study. Those questions with the findings from the study follow.

1. How much training do the pastors have in fulfilling the role of counselor?

Nine pastors had some type of training while in college; fourteen had counseling training while in seminary. Seventeen received counseling training from sources other than college or seminary. Nine pastors had no such counseling training. In general, seventy-nine percent of the pastors received some type of counseling training. Twenty-eight or sixty-seven percent of the pastors had some type of counseling training since entering the pastorate. Of the twenty-eight, eight pastor's only type of training was Basic Youth Conflicts. Forty-eight percent or twenty of the pastors had training other than Basic Youth Conflicts since entering the pastorate.

2. How important does the pastor feel his counseling is to his total ministry?

In general, most of the pastors believed that counseling was an important aspect of their ministry. The one pastor who did not think 
counseling was important to his ministry felt this because the older congregation that he served was not given to calling on the pastor for counsel.

The amount of time spent in sounseling sessions per week ranged from under three to between eleven and fifteen hours. Fifty-four percent of the pastors spent between three and five hours a week in counseling sessions.

3. How much ease does the pastor feel in the role of a counselor?

The amount of ease was measured in terms of the different roles the pastor may have to fulfill while counseling. In general, the pastors felt the greatest degree of ease as a spiritual guide and as a listener. A moderate amount of ease was felt as an advisor and as a motivator. The least amount of ease felt by the pastors was as a therapist. 4. What does the pastor see as his main role while counseling? In general, three roles were thought to be the main ones of the pastors while counseling. They were the roles of spiritual guide, of a comforter, and of a listener.

5. What types of techniques do the pastors utilize while counseling?

The pastors utilized the same types of counseling techniques as used by social workers. The techniques most often used was clarification. The techniques of confrontation, ventilation, interpretation, support, information giving, persuasion, solicit reaction support and advice giving in general were used sometimes by the pastors. Logical discussion and investigation in general were used by the pastors often. Solicit reaction counteract, limit setting, and demonstrating behavior were techniques that seldom were used by the pastors. Conscious permissive- 
ness was very seldom used by the pastors. In general, the pastors utilized a variety of techniques while counseling, but, tended to rely on a few techniques more than others.

6. How does the pastor as a counselor handle different situations? In general, the pastor looked for the same types of things that social workers look for. In addition most pastors take into consideration whether the person is a Christian.

In counseling an adolescent, the pastors, in general, considered the building of a relationship to be of major importance. In this type of counseling, they also considered whether the adolescent was a Christian.

In general, the pastors thought there was some truth concerning the making of value judgements about the client's behavior and that a counselor should avoid putting his value system onto the client. The pastors, it seemed, were unsure as to the importance of making value judgements about the client's behavior and the putting of one's value system onto another. Most of the pastors felt that problems should be treated as a spiritual problem and an emotional problem for the best results.

7. What difference in counseling exists between pastors who have had counseling training since entering the pastorate and those who have not had counseling training since entering the pastorate?

In general no difference existed between those who have had counseling training since entering the pastorate and those who have not had counseling training since entering the pastorate in the way that they handled different situations. Thirteen pastors who had not had counseling training since entering the pastorate had training in college or seminary.

The pastors who had had no counseling training what so ever felt 
a significatly higher degree of ease for counseling non-church members, counseling church members, counseling a person with a different value system, counseling a person with a spiritual problem and counseling a family than those pastors who had had three or more types of counseling classes since entering the pastorate.

\section{RECOMMENDATIONS}

The following are recomnendations made as a result of this study:

1. That those pastors who have a real interest in developing the counseling aspect of their ministries make themselves available for counseling sessions and encourage their members to seek them out. The basis for this recommendation is the incongruence between the amount of importance the pastors felt that counseling played in their ministry and the amount of time spent per week in counseling sessions.

2. That the Pacific Northwest Conference office provide additional counseling training for the pastors in the areas of family counseling, marital counseling, adolescent counseling, and counseling with the alcoholic. Additional training in working with the alcoholic would benefit the pastors as this is the area of the least amount of ease among the counseling problems.

IMPLICATIONS FOR FUTHER STUDY

This is a pilot study establishing certain foundations for further and more exhaustive research. In order to obtain a more realistic picture of the field of pastoral counseling, personal interviews probably should be conducted with all the pastors. This would allow for the use of 
open ended questions and for the expression of feelings. It would also give the researcher a means of observing how the pastor comes across. The effectiveness of the pastor's counseling sessions were not measured. This may be another area for exploration. In times when accountability and results are being researched in the mental health professions, ministers should also be concerned about how they measure up to the helping professions in these areas.

Oates (1962, p. 23.) said

"These four challenges, then - the challenge of community, the challenge of history and identity, the challenge of the sovereignty of man, and the challenge of competence - all necessitate an agonizing reappraisal of pastoral counseling in terms of the theological claims upon the lives of the minister and his counselee."

The challenge becomes real because as Clinebell (1966, p 196)

said

"The pastor, regardless of his training, does not enjoy the privilege of electing whether or not he will counsel with his people . . His choice is not between counseling and not counseling but between counseling in a disciplined and skilled way, and counseling in an undisciplined and unskilled way."

\section{CONCLUSION}

This study, while being a pilot study, has provided an insight into the field of pastoral counseling as it exists within the Pacific Northwest Conference of the Free Methodist Church. It has furnished an overview of the techniques utilized by the pastors in the counseling sessions. Also furninshed by the study was an insight into the amount of ease felt by the pastors in their various counseling roles and situations. 
SELECTED BIBLTOGRAPHY

Adams, Jay E. Competent to Counsel. Grand Rapids, Michigan: Baker Books, 1970.

Adams, Jay E. The Christian Counselor's Manuel. Grand Rapids, Michigan: Books, 1973.

Aldrich, C. Knight and Carl Nighswonger. A Pastoral Counseling Casebook. Philadelphia: The Westminister Press, 1968.

Clinebell, Howard J. Basic Types of Pastoral Counseling. Nashville: Abingdon Press, 1966.

Doniger, Simon. The Minister's Consultation Clinic. Great Neck, New York: Channel Press Inc., 1958.

Downie, N. M. and R. W. Heath. Basic Statistical Methods. New York: Harper and Row, 1970.

Eaton, Joseph W. et al. "Pastoral Counseling in a Metropolitan Suburb," Journal of Pastoral Care. (Summer, 1963), 93-105.

Gurin, J. W. and Sheila Feld. Americans View Their Mental Health. New York: Basic Books, 1960.

Hiltner, Seward. Pastoral Counseling. New York: Abingdon Press, 1949.

Hiltner, Seward.and Lowell G. Colston. The Context of Pastoral Counseling. Nashville: Abingdon Press, 1961.

Kemp, Charles F. A Pastoral Counseling Guidebook. Nashville: Abingdon Press, 1971.

Mikesell, William H. Counseling for Ministers. Boston: The Christopher Publishing House, 1961.

Morris, William, (ed.). The American Heritage Dictionary of the English Language. Boston: American Heritage Publishing Co.. Inc. and Houghton Mifflin Company, 1970.

Oates, Wayne (ed.). An Introduction to Pastoral Counseling. Nashville: Boardman Press, 1959.

Oates, Wayne E. Pastoral Counseling. Philadelphia: The Westminister Press, 1974.

Oates, Wayne E. Protestant Pastoral Counseling. Philadelphia: The Westminister Press, 1962. 
Oden, Thomas C. Kerygma and Counseling. Philadelphia: The Westminister Press, 1966.

Olsen, Peder. Pastoral Care and Psychotherapy. Minneapolis: Augsburg Publishing House, 1961.

Stein, Calvert. Practical Pastoral Counseling. Springfield, Illinois: Charles C. Thomas Publishers, 1970.

Stone, Howard W. Suicide and Grief. Philadelphia: Fortress Press, 1972.

Switzer, David K。 The Minister as a Crisis Counselor. Nashville: Abingdon Press, 1974.

Wise, Carrol A. Pastoral Counseling, Its Theory and Practice. New York: Harper and Brothers, 1951.

Woodruff, Thomas O. "A Study Describing Pastoral Counseling Among the Christian Church Ministers in Oregon with Special Emphasis on the Counseling Training that They Received at Northwest Christian College." Unpublished Master's Practicum, Portland State University, 1973. 


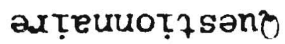

XICNAddV 
The number at the top of this page has been given in order for me to know who returned the questionnaire and who did not return the questionnaire. As soon as I receive your questionnaire I will remove the number in order for anonymity and condidentiality to be maintained.

DIRECTIONS: Please write in the appropriate answer where a write-in answer is needed. Please check the answer that comes closest to what you believe where this is called for. There are no "right" or "wrong" answers. If you are unable to answer a question; skip that question and finish the rest of the questionnaire. It is important that every questionnaire is returned in order for there to be an accurate representation.

1. How many years have you been in the pastorate full-time?

2. Please check the highest level of formal education that you have achieved?

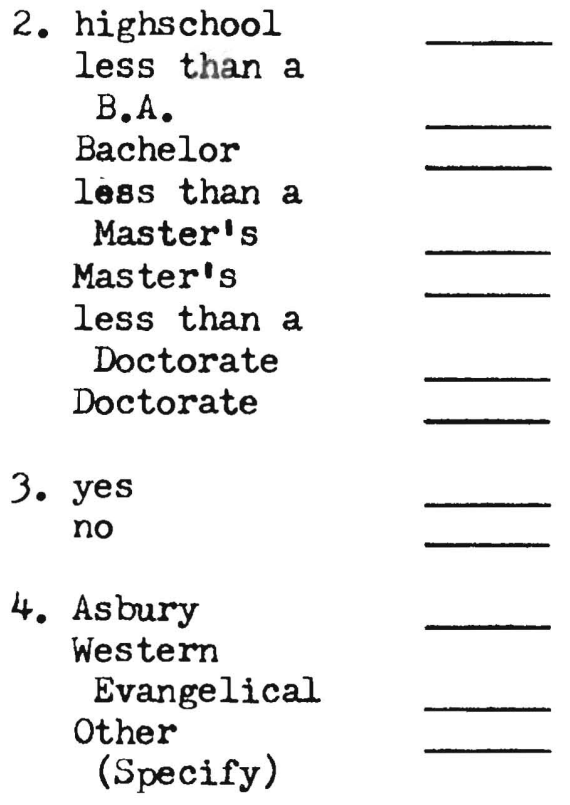

3. Did you attend seminary?

4. Which seminary did you attend?

1.

$\begin{array}{ll}\text { 2. highschool } & \\ \text { less than a } & \\ \text { B.A. } & \\ \text { Bachelor } & \\ \text { less than a } & \\ \text { Master's } & \\ \text { Master's } & \\ \text { less than a } & \\ \text { Doctorate } & \\ \text { Doctorate } & \\ & \\ \text { 3. yes } & \\ \text { no } & \\ \text { 4. Asbury } & \\ \text { Western } & \\ \text { Evangelical } & \\ \text { Other } & \\ \text { (Specify) } & \\ \end{array}$

5. Were any counseling classes offered by the seminary?

5. yes

no

6. Have you taken any counseling courses?

6. in college in seminary other

no

7. If yes, please check the subjects covered by the classes?

7. counseling theory

Family Marital individual adolescent other(specify) 
8. Have you taken any counseling or training 8. yes classes since entering the pastorate? no

9. If yes, please check which type?

9. marital

pre-marital

Family Therapy Transactional Analysis Gestalt Reality Therapy Basic Youth Conflicts Other(Specify)

10. How large is your congregation?

10. under 50

50-99

100-149

$150-199$

$200-249$

250-299

$300-349$

350-399

400 and over

11. As an average, how many hours a week do you spend counseling?

11. under 3

$3-5$

$6-10$

$11-15$

16 - 20

21 and over

12. Where do most of your counseling sessions 12. over telephone take place? (Please rank from 1 - 5, with 1 being where most take place.) person's home parsonage your office other (specify)

13. As an average, how long do your counseling13. under 30 min. sessions last?

30 - $49 \mathrm{~min}$. 50 - 89 min. $90 \mathrm{~min}$ and over

14. In your opinion, how important is counseling to your total ministry?

14. not important somewhat moderately important very important 
15. In the types of counseling situations at the right, please show how much ease you generally feel. Beside each type place any number from 0 to 100 with 0 for "no ease" and on up to 100 for "perfect ease."

16. In actual counseling relationships, how important are the accompanying goals as a rule? Please mark 0 for "no importance" on up to 100 for maximum importance.

17. Please check which role you consider to be your main role while counseling?
15. marital pre-marital family adolescent individual alcoholic non-church member church member person with spiritual problem person with different value sys iem

16. to help the person to feel better about himself

to help the person to resolve conflict

to bring the person to a greater relationship with God

to help the person become more functional

to help the person achieve the goals that he has set for himself

17. advisor comforter listener motivator therapist helper spiritual guide other (specify) 
18. In the roles at the right, please show how wuch at ease you generally feel. Beside each role place any number from 0 to 100 with 0 for "no ease" and up to 100 for "perfect ease."

19. How ofen do you consciously use the techniques at the right while counseling? Please rate them using 1 for very seldom; 2 for seldom; 3 for sometimes; 4 for often and 5 for very often.
18. advisor comforter listener motivator therapist helper spiritual guide other (specify)

19. confrontation clarification ventilation limit setting interpretation suppor. demonstrate behavior give information persuasion advice conseious permissiveness logical

discussion investigation solicit reaction (support) solicit reaction (counteract) purpose program ther (specify) 
20. A disraught mother brings her thirteen year old son into your office. The boy has just been suspended from school for smoking marijuana. The mother, a member of your church, doesn't know what to do. She starts the conversation by saying. "His father and I have tried to give John the best of everything and this is the way that he repays us." Please check the response that comes the closest to how you would handle the situation.

To reassure and support the parents.

20.

To tell John that he is wrong to smoke marijuana because Chrisitians shouldn't do that.

To explore with John some of the things that are happening at school and at home.

Ask the mother to leave and try to build a relationship with John.

To explore with John and his mother some of the things that are happening within the family.

Other (specify)

21. What would you do first in counseling this mother and son? Please check the answer that comes the closest to how you would handle the situation.

Find out the facts behind the incident.

21

Reassure and comfort John.

Reassure and comfort Mom.

Find out what expectations they have of you.

Other (specifiy)

22. Where would you go from this step during the session? Please check the answer that comes closest to how you would handle the situation.

Find out what things are going on at home. (any difficulties between or with mom and dad)

22.

Find out how John is doing in school.

Discuss ways of punishing John.

Setting and clarifying goals for the session. Other (Specify) 
23. In counseling a family what things do you consider to be important. Please check all that are applicable.

The interactions that take place in the office. How the parents are getting along. Whether the family members are Christian. The family history. The family's reason for coming in. How many things the family does together. The ages of the children. Other (specify)

24. In counseling adolescents what things do you consider to be important. Please check all that are applicable.

The behavior that the person has been exhibiting. 24 . The value system of the person. Whether the person is a Christian. The things that the parents want the teenager to do. The way that the person feels about himself. Other (specify)

25. The following statements are typical statements about counseling. Please indicate how much truth you think that there is to each statement. Please circle L for little or none, S for some, and $M$ for much or all.

A counselor should try not to make value judgements about the client's behavior.

A counselor should not communicate to the client his ideas about the rightness or wrongness of the client's behavior.

A goal of counseling is human betterment.

A counselor should look at his client in terms of the client's total life situation.

An important characteristic of a counselor is compassion. L S M A counselor should try to relieve a elient's guilt and $L$ S $M$ anxiety.

All clients are individuals and should be treated as such. L S M

A counselor need to structure the counseling session in order for the client to benefit from the session.

L S M

A counselor should give advice to his client. 
Change in a person begins when the person makes the

L $\quad S \quad M$ decision that he is going to change.

The relationship between the client and the

L S M counselor is one of the most important aspects of the counseling situation.

As a counselor, the pastor muat remember that he

L S M represents God's law to his clients.

A counselor should avoid putting his value system

L S M on the client.

The responsibility for change is on the client.

L S M

It is often better to do things for the client, than to get the client to do things for himself.

L S M

A counselor should trest the spiritual problem and

L S M the mental problem will go away.

A counselor should treat the problem as an emotional

L $\quad S \quad M$ mental problem and the spiritual problem will go away.

A counselor should treat the problem as being both a

L S M spiritual and an emotional problem for the best results.

A person's mental health has very little to do with

L $\quad S \quad M$ spiritual problems. 